\title{
Percutaneous embolization: a viable treatment option for varicocele
}

\author{
Ranjith Ramasamy
}

There are several options in the treatment of varicocele. Surgical repair either by open or microsurgical approach, laparoscopy, or through percutaneous embolization of the internal spermatic vein have been used to treat varicocele [1]. Regardless of the chosen technique, the ultimate goal relies on the occlusion of the dilated veins that drain the testis. Percutaneous embolization offers a rapid recovery and can be successfully accomplished in approximately $90 \%$ of attempts. However, the technique demands interventional radiologic expertise and has potential serious complications, including vascular perforation, coil migration, and thrombosis of pampiniform plexus [2].

Prasivoravong et al. [3] report results from a case series of men undergoing varicocele embolization. They evaluated men with grade III unilateral varicocele and identified improvements in sperm morphology. Percutaneous embolization can be a valuable treatment option for recurrences after surgery since patients may not want to undergo another operation and surgeons may not feel comfortable with artery and lymphatic sparing technique. Percutaneous approach can offer a viable treatment approach for men complaining of scrotal pain (orchialgia) from varicocele because inflammation and scarring from operation may contribute to additional pain.

Further studies are necessary to determine the benefit of percutaneous embolization in men with bilateral and lower grades of varicocele. Additional comparative studies comparing the different treatment options for varicocele can help determine the best treatment option for men that present with varicocele-associated infertility.

\section{Competing interests}

The author declares that he has no competing interests.

Received: 7 May 2014 Accepted: 22 May 2014

Published: 2 June 2014

\section{References}

1. Shlansky-Goldberg RD, VanArsdalen KN, Rutter CM, Soulen MC, Haskal Z, Baum RA, Redd DC, Cope C, Pentecost MJ: Percutaneous varicocele embolization versus surgical ligation for the treatment of infertility: changes in seminal parameters and pregnancy outcomes. J Vasc Interv Radiol 1997, 8(5):759-67.

2. Choi WS, Kim SW: Current issues in varicocele management: a review. World J Mens Health 2013, 31(1):12-20.

3. Prasivoravong J, Marcelli F, Lemaître L, Pigny P, Ramdane N, Peers M-C, Mitchell V, Rigot J-M: Beneficial effects of varicocele embolization on semen parameters. Basic Clin Androl 2014, 24:9.

\section{doi:10.1186/2051-4190-24-10}

Cite this article as: Ramasamy: Percutaneous embolization: a viable treatment option for varicocele. Basic and Clinical Andrology 2014 24:10.
Correspondence: ranjithrama@gmail.com

Department of Urology, Baylor College of Medicine, Houston, Texas 77030, USA

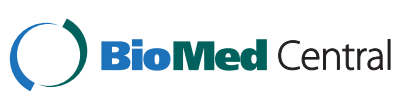

(c) 2014 Ramasamy; licensee BioMed Central Ltd. This is an Open Access article distributed under the terms of the Creative Commons Attribution License (http://creativecommons.org/licenses/by/4.0), which permits unrestricted use, distribution, and reproduction in any medium, provided the original work is properly credited. The Creative Commons Public Domain Dedication waiver (http://creativecommons.org/publicdomain/zero/1.0/) applies to the data made available in this article, unless otherwise stated.

\section{Submit your next manuscript to BioMed Central and take full advantage of:}

- Convenient online submission

- Thorough peer review

- No space constraints or color figure charges

- Immediate publication on acceptance

- Inclusion in PubMed, CAS, Scopus and Google Scholar

- Research which is freely available for redistribution 